Jurnal Mandala Pharmacon Indonesia, Vol 4.No.2Desember 2018

Avaiable online at www.jurnal-pharmaconmw.com/jmpi

$p$-ISSN : 2442-6032

e-ISSN : 2598-9979

\title{
Evaluasi Penggunaan Antibiotik Pada Anak Penderita Bronkopneumonia Di Rumah Sakit Provinsi Sulawesi Tengah Periode 2017
}

Syafika Alaydrus

Program Studi DIII Farmasi, Sekolah Tinggi Ilmu Farmasi Pelita Mas

\begin{abstract}
ABSTRAK
Bronkopneumonia adalah radang paru yang berasal dari cabang-cabang tenggorakan yang mengalami infeksi dan tersumbat oleh getah radang, sehingga menimbulkan pemadatanpemadatan bergerombol dalam lobolus paru yang berdekatan. Penelitian ini bertujuan untuk mengetahui penggunaan antibiotik pada pasien anak penderita penyakit Broncopneumonia di Rumah Sakit Periode Januari-juni 2017. Penelitian ini beirifag observasional menggunakan rancangan cross-sectional, subyek penelitian adalah pasien anak yang menderita Bronkopnemonia, metode pengambilan sampel adalah purposive sampling, jumlah sampel dalam penelitian ini dihitung menggunakan rumus slovin, hasil prhitungan didapatkan jumlah sampel sebanyak 35 sampel. Analisis data dalam penelitian ini dilakukan dengan cara
\end{abstract}

\section{PENDAHULUAN}

Bronkopnemonia adalah peradangan pada paru-paru yang mengenai satu atau beberapa lobus diparu-paru yang ditandai dengan adanya bercak-bercak infiltrate yang disebabkan oleh bakteri, virus, jamur dan benda asing. Bronkopnemonia disebut juga pneumonia loburalis dan dinyatakan mencatat hasil diagnosis. Hasil penelitian menunjukan bahwa evaluasi penggunaan antibiotik berdasarkan tepat indikasi nilainya $100 \%$, tepat obat nilainya $100 \%$, tepat pasien $100 \%$ dan tepat dosis nilainya $100 \%$. Pemberian antibiotik lebih mengutamakan antibiotik golongan sefalosporin generasi ketiga yaitu Cefadroxil (14,29\%), cefotaxime (45,24\%), cefixime $(21,43 \%)$ dan ceftriaxone $(19,04 \%)$.

Kata kunci : Broncopneumonia, Antibiotik, Evaluasi Pengobatan, Infeksi

Penulis Korespondensi :

Syafika Alaydrus

Program Studi DIII Farmasi, Sekolah Tinggi Ilmu Farmasi Pelita Mas

E-mail : syafikaalaydrus39@gmail.com dengan adanya daerah infeksi yang bebercak dengan adanya daerah infeksi sekitar 3-4 cm yang mengelilingi dan melibatkan bronkus. (Fadhila, 2013)

Bronkopnemonia seringnya disebabka oleh bakteri. Bakteri-bakteri ini mampu menyebar dalam jarak dekat melalui percikan ludah saat penderita bersin atau batuk, yang kemudian 
terhirup oleh orang disekitarnya. Inilah sebabnya lingkungan menjadi salah satu factor risiko berkembangnya bronkopnemonia. (Ramadheni, 2018)

Pnemonia di Indonesia, menjadi penyebab kematian yang masuk dalam 10 penyakit terbesar tiap tahunnya. bayi dan balita mencapai 22,23\% (Kemenkes RI, 2017). Tahun 2012 kejadian pneumonia di Indonesia pada balita mencapai 10\%-20\% dengan angka kematian 6 per 1000 kelahiran hidup. Kejadian pneumonia dii Indonesia merupakan kejadian ke-6 terbesar di dunia (WHO, 2006). Pneumonia cenderung terjadi pada anak laki-laki yang berdasarkan beberapa pendapat bahwa dominasi kejadian Bronchiolitis yaitu pada anak laki-laki yang dirawat 1,25-1,6 kali lebih banyak dari perempuan atau sebanyak 63\% yang disebabkan berat badan lahir rendah, tidak mendapatkan ASI eksklusif, tidak mendapatkan imunisasi secara lengkap, paparan asap rokok dan populasi, defisiensi vitamin A dan gizi buruk (IDAI 2010).

Penggunaan antibiotik yang rasional diharapkan dapat meningkatkan efktifitas terapi dan membatasi laju resistensi. Efek peresepan antibiotik yang kurang tepat juga dapat meningkatkan kejadian resistensi. Penggunaan antibiotic untuk bronkopneumania harus selalu didasarkan pada indikasi yang baik dan tepat. Jika indikasi tidak sesuai, bisa terjadi resistensi dan mempengaruhi proses penyembuhan penyakit (Erfand.,Dkk. 2018).

Bronkopnemonia biasanya akan sembuh dalam waktu satu atau beberapa minggu, namun kesembuhan juga bergantung pada jenis organism yang menginfeksi, usia, kondisi kesehatan, dan tingkat keparahannya. Mengikuti seluuruh rangkaian pengobatan hingga tuntas sangatlah penting agar tidak terjadi komplikasi atau menyebabkan resistensi bakteri terhadap antibiotik. (Kemenkes RI, 2011).

Berdasarkan hal tersebut, mendorong peneliti untuk melakukan penelitian terhadap evaluasi penggunaan antibiotik pada pasien anak penderita penyakit broncopneumonia di Rumah Sakit Provinsi Sulawesi Tengah periode Januari - juni 2017.

\section{METODE PENELITIAN}

Penelitian yang dilakukan bersifat observasional dengan menggunakan rancangan cross-sectional. Data yang diambil retrospektif yang ditelusuri dari rekam medik pasien yang menderita Bronkopnemonia. Kriteria Inklusi 
meliputi pasien anak dengan umur 0 bulan - 11 tahun yang terdiagnosa akhir penyakit broncopneumonia, sedangkan kriteria ekslusi meliputi data rekam medik pasien pneumonia yang tidak lengkap atau rusak dan pasien memiliki penyakit penyerta serta tidak diberikan antibiotik. Metode Pengambilan sampel adalah Purposive Sampling. Sampel dalam penelitian ini yakni sebagian pasien anak yang menderita penyakit Broncopneumonia yang tercatat dalam rekam medik periode 2017, besar sampel dalam penelitian ini di dapatkan dengan menggunakan rumus Solvin :

$$
n=\frac{N}{1+N e^{2}}
$$

Dengan tingkat kepercayaan 95\%, sehingga didapatkan jumlah sampel yaitu 42.

Penilaian kesesuaian dilakukan berdasarkan literatur yang digunakan yaitu buku Pharmaceutical Care untuk saluran Pernapasan tahun 2005, Pediatric
Dose Handbook (PDH), dan Informatorium Obat Nasional Indonesia (IONI). Data yang diambil adalah data karakteristik pasien yang meliputi jenis kelamin dan usia. Data pengobatan yang diambil meliputi nama obat, kekuatan obat, jumlah obat serta dosis yang diterima selama pengobatan.

\section{ANALISIS DATA}

Analisis data dalam penelitian inii dilakukan dengan cara mencatat hasill diagnosis atau terapi yang digunakan pada pasien anak broncopneumonia. Setelah data diperoleh kemudian data dianalisis secara deskriptif presentase. Data akan dinyatakan dalam bentuk persentase yang dilakukan dengan cara melihat dan mengevaluasii penggunaan antibiotik kemudian dibandingkan dengan standar yang ada, yaitu 4T 1W. Setelah menganalisis data dalam bentuk persentase, kemudian hasilnya akan disajikan dalam bentuk tabel dan narasi.

1. Tepat Indikasi

Persentase tepat indikasi dihitung sesuai rumus dibawah ini :

$$
\text { Tepat Indikasi }=\frac{\text { Persentase Tepat Indikasi }}{\text { Banyaknya Pasien }} \times 100 \%
$$

2. Tepat Obat

Persentase tepat obat dihitung sesuai rumus dibawah ini :

$$
\text { Tepat Obat }=\frac{\text { Persentase Tepat Obat }}{\text { Banyaknya Pasien }} \times 100 \%
$$


3. Tepat Pasien

Persentase tepat pasien dihitung sesuai rumus dibawah ini

$$
\text { Tepat Pasien }=\frac{\text { Persentase Tepat Pasien }}{\text { Banyaknya Pasien }} \times 100 \%
$$

4. Tepat Dosis

Persentase tepat dosis dihitung sesuai rumus dibawah ini

$$
\text { Tepat Dosis }=\frac{\text { Persentase Tepat Dosis }}{\text { Banyaknya Pasien }} \times 100 \%
$$

5. Waspada Efek Samping

Persentase waspada efek samping dihitung sesuai rumus dibawah ini

$$
\text { Waspada Efek Samping }=\frac{\text { Persentase Efek Samping }}{\text { Banyaknya Pasien }} \times 100 \%
$$

Setelah menganalisis data dalam bentuk persentase, kemudian hasilnya akan disajikan dalam bentuk tabel dan narasi.

\section{HASIL PENELITIAN}

Analisa kuantitatif penderita infeksi bronkopnemonia pada penelitian ini meliputi jumlah persentase pasien bronkopnemonia di ruang rawat inap penyakit dalam RSU. Provinsi Sulawesi Tengah selama bulan januari - juni 2017 berdasarkan jenis kelamin, usia, distribusi antibiotic, bentuk sediaan antibiotik dan jenis cairan elektrolit. Jumlah pasien bronkopnemonia pada pnelitian ini adalah 42 orang. Hasil analisa jumlah pasien bronkopnemonia berdasarkan kategori jenis kelamin, usia, distribusi antibiotik, bentuk sediaan antibiotik, jenis cairan elektrolit serta evaluasi ketepatan antibiotic dapat dilihat pada tabel dibawah ini : 
Tabel 1. Persentase Karakteristik Pasien Anak Broncopneumonia di RS. Provinsi SULTENG

\begin{tabular}{|c|c|c|c|}
\hline NO & KARAKTERISTIK & $\mathrm{N}(42)$ & PERSENTASE (\%) \\
\hline \multirow[t]{3}{*}{1} & Jenis Kelamin & & \\
\hline & 1) Pria & 28 & $66,67 \%$ \\
\hline & 2) Wanita & 14 & $33,33 \%$ \\
\hline \multirow[t]{3}{*}{2} & Usia & & \\
\hline & 1) 0-5 tahun & 27 & $64,29 \%$ \\
\hline & 2) 6-11 tahun & 15 & $35,71 \%$ \\
\hline
\end{tabular}

Sumber : Data Rumah Sakit Provinsi Sulawesi Tengah

Tabel 2. Karakteristik Distribusi Antibiotik, Bentuk Sediaan Pada Pasien Anak Broncopneumonia di RS. Provinsi SULTENG

\begin{tabular}{lccc}
\hline NO & Antibiotik & FREKUENSI(N & PERSENTASE \\
& $=42)$ & $(\%)$ \\
\hline
\end{tabular}

$1 \quad$ Distribusi Antibiotik
1) Cefadroxil
6
$14,29 \%$
2) Cefotaxime
19
$45,24 \%$
3) Cefixime
9
$21,43 \%$
4) Ceftriaxone
8
$19,04 \%$

\section{Total}

$100 \%$

\section{Bentuk Sediaan Antibiotik}
1) Sirup
15
$35,71 \%$
2) Injeksi
27
64,29

\section{Total}

$100 \%$

Sumber : Data Rumah Sakit Provinsi Sulawesi Tengah 
Tabel 3. Cairan Elektrolit yang digunakan Pada Pasien Anak Broncopneumonia di RS.

Provinsi SULTENG

\begin{tabular}{cccc}
\hline \multirow{2}{*}{ NO } & $\begin{array}{c}\text { JENIS CAIRAN } \\
\text { ELEKTROLIT }\end{array}$ & N & PERSENTASE (\%) \\
\hline 1 & Ringer Laktat & 32 & $76,19 \%$ \\
\hline 2 & Dextrose 5 \% & 10 & $23,81 \%$ \\
\hline & Total & $\mathbf{4 2}$ & $\mathbf{1 0 0}$ \\
\hline
\end{tabular}

Sumber : Data Rumah Sakit Provinsi Sulawesi Tengah

Tabel 4. Evaluasi Ketepatan (Indikasi, Obat, Pasien, Dosis \& Efek Samping) Penggunaan Antibiotik Pada Pasien Anak diRS. Provinsi SULTENG

\begin{tabular}{lcccc}
\hline \multirow{2}{*}{ KRITERIA } & \multicolumn{2}{c}{ JUMLAH } & \multicolumn{2}{c}{ PERSENTASE (\%) } \\
\cline { 2 - 5 } KERASIONALAN & SESUAI & $\begin{array}{c}\text { TIDAK } \\
\text { SESUAI }\end{array}$ & SESUAI & TIDAK SESUAI \\
\hline Tepat Obat & 42 & - & $100 \%$ & - \\
\hline Tepat Indikasi & 42 & - & $100 \%$ & - \\
\hline Tepat Pasien & 42 & - & $100 \%$ & - \\
\hline Tepat Dosis & 42 & - & $100 \%$ & - \\
\hline Waspada Efek & 42 & - & $100 \%$ & \\
Samping & & & & \\
\hline
\end{tabular}

Sumber : Data Rumah Sakit Provinsi Sulawesi Tengah

\section{PEMBAHASAN}

1. Karakteristik Pasien

a) Jenis Kelamin

Berdasarkan hasil penelitian, pasien anak penderita penyakit pneumonia di RS. Provinsi SULTENG Palu periode januari - juni 2017 lebih banyak terjadi pada anak dengan jenis kelamin laki-laki dengan persentase
$66,67 \%$ dan untuk jenis kelamin perempuan sebesar 33,33\%. Hal ini diperkuat dengan hasil penelitian putri ramadheni dan raveinal yang menyebutkan bahwa dari 133 orang penderita bronkopnemonia 71 orang penderita berjenis kelamin laki-laki. Hal ini disebabkan karena laki-laki lebih beresiko terkena broncopneumonia 
karena anak laki-laki lebih sering bermain di luar rumah sehingga keterpaparan udara lebih banyak dari pada anak perempuan yang dominan bermain di dalam rumah (Suhandayani. 2006).

Jenis kelamin merupakan salah satu faktor risiko pneumonia. Karakteristik penderita penyakit pneumonia berjenis kelamin laki-laki memiliki resiko lebih tinggi yaitu sebesar 19\% dibandingkan yang berjenis kelamin perempuan yaitu sebesar 18\%. (Kemenkes RI 2013).

\section{b) Usia}

Pasien anak penderita penyakit bronkopneumonia di RS. Provinsi Sulawesi Tengah periode Januari - juni 2017 berada pada rentang usia 0-11 tahun. Kriteria usia pada penelitian ini dibagi menjadi 2 bagian usia yaitu usia 0-5 $(64,29 \%)$ tahun dan $6-11$ (35,71\%) tahun, dimana penyakit bronkopneumonia lebih banyak terjadi pada rentang usia antara 0-5 tahun. bronkopneumonia lebih sering terjadi pada anak usia $<6$ tahun yang berkaitan dengan respon anak karena secara biologis sistem pertahanan tubuh laki-laki dan perempuan berbeda. Organ paru pada perempuan memiliki daya hambat aliran udara lebih rendah dan daya hantar aliran udara yang lebih tinggi sehingga sirkulasi udara dalam rongga pernapasan lebih lancar dan paru terlindungi dari infeksi pathogen (Uekert dkk, 2006).

\section{Karakteristik Antibiotik}

\section{a) Distribusi Antibiotik}

Berdasarkan dari karakteristik antibiotik pada tabel 2 nomor 1, dapat dilihat bahwa antibiotik yang digunakan pada banyak terapi anak umur $0-11$ tahun di RS Provinsi Sulawesi Tengah adalah antibiotik golongan sefalosporin generasi ketiga yaitu cefadroxil, cefotaxim, cefixime dan ceftriaxone, berdasarkan pedoman WHO, penggunaan antibiotic tunggal yang harus digunakan untuk penderita bronkopnemonia adalah golonga penisilin dan sefalosporin. Kedua gologan antibiotic ini merupakan blood spectrum yang memiliki aktivitas baik terhadap bakteri gram positif dan gram negative dan aktif melawan S.Pnemonia (Erfand,Dkk, 2018)

\section{b) Bentuk Sediaan Antibiotik}

Pada tabel 2, pemberian antibiotik dalam bentuk injeksi mencapai 64,29\% yang dilakukan pada anak penderita penyakit bronkopneumonia berat, dimana penderita tidak dapat makan dan minum bahkan muntah-muntah sehingga pemberian antibiotik secara oral tidak 
memungkinkan. Adapun pemberian antibiotik secara oral yaitu dalam bentuk sirup sebanyak $35,71 \%$ pada anak penderita penyakit pneumonia yang tidak memiliki kesulitan dalam menelan karena pemberian antibiotik secara oral lebih aman (Pudjiaji dkk, 2009). Pemberian antibiotik dalam bentuk sediaan injeksi lebih banyak, Hal ini bertujuan untuk membantu atau memudahkan bagi pasien untuk menerima distribusi antibiotik karena pasien mengalami kesulitan dalam menelan dan juga untuk mempercapat efek yang diinginkan dengan cara merobek jaringan kulit atau selaput lendir (Graber, MA. 2003)

\section{c) Cairan Elektrolit}

Pada tabel 3, menunjukan bahwa penggunaan cairan elektrolit seperti Ringer Laktat (RL) sebanyak 76,19\% dan Dextrose 5\% sebanyak 23,81\% Cairan elektrolit biasanya digunakan sesuai dengan kondisi pasien. Pemberian cairan elektrolit digunakan untuk menjaga keseimbaangan cairan tubuh pasien. Keseimbangan elektrolit berpengaruh terhadap kinerja sel-sel dan organ tubuh agar bekerja optimal. Cairan elektrolit sangat dibutuhkan dalam proses pengobatan penyakit bronkopneumonia pada anak. Pemberian cairan Ringer
Laktat berfungsi sebagai cairan elektrolit untuk menjaga keseimbangan elektrolit dalam tubuh dan sebagai air untuk hidrasi dimana pasien anak penderita penyakit pneumonia sering mengalami kesulitan dalam menelan. Sedangkan pemberian pemberian cairan Dextrose 5\% bertujuan untuk memasok glukosa dalam tubuh yang berfungsi sebagai sumber energy (Anwari, 2007).

\section{d) Evaluasi Penggunaan Antibiotik}

\section{1) Tepat Indikasi}

Ketepatan indikasi pada panggunaan antibiotik dilihat dari ketepatan pemberian obat yang sepenuhnya berdasarkan alasan medis dan terapi farmakologi benar-benar diperlukan. Menurut data RS. Provinsi Sulawesi Tengah periode 2017 menunjukan bahwa bronkopneumonia memenuhi kriteria tepat indikasi terhadap antibiotik yang didistribusikan karena sesuai dengan tanda-tanda yang tercantum dalam rekam medik dan hasil diagnosa yang menunjukan bahwa perlu adanya terapi antibiotik. .Pemakaian antibiotik tanpa didasari bukti infeksi dapat menyebabkan meningkatnya insiden resistensi maupun potensi Reaksi Obat Berlebihan (ROB) (Depkes, 2005). Pemberian antibiotik pada 42 pasien anak penderita penyakit bronkopneumonia 
tanpa penyakit penyerta di Rumah Sakit Provinsi Sulawesi Tengah dari umur 0 bulan - 11 tahun periode januari - Juni 2017, 100\% tepat indikasi.

\section{a) Tepat Obat}

Ketepatan pemilihan obat harus berdasarkan pedoman dan diagnosis pneumonia. Antibiotik golongan sefalosporin generasi ketiga merupakan antibiotik yang paling banyak diresepkan yaitu cefadroxil (14,29\%), cefotaxime $(45,24 \%), \quad$ cefixime $(21,43 \%)$ dan ceftriaxone $(19,04 \%)$, hal ini juga didukung oleh penelitian Made virgo dari 77 pasien yang diambil dari data sekunder 77 pasien tersebut juga menggunakan obat cefotaxime dan ceftriaxon. Berdasarkan diagnosis yang tepat maka harus dilakukan pemilihan obat yang tepat. Tepat obat berkaitan dengan kelas terapi dan jenis obat berdasarkan pertimbangan manfaat, keamanan, harga dan mutu obat pada pasien penderita penyakit bronkopneumonia. Pemilihan jenis obat yang tidak tepat, dapat menyebabkan pengobatan yang tidak sesuai dengan indikasi dan dapat menimbulkan efek samping bahkan gejala-gejala yang dapat berakibat fatal (Gunawan, 2007). Pengobatan untuk pasien pneumonia diberikan antibiotik yang efektif terhadap organisme tertentu (Price \& Wilson, 2006), b) Tepat Pasien

Dari penelitian yang dilakukan terhadap 42 data rekam medik pasien pneumonia diperoleh nilai penggunaan obat berdasarkan tepat pasien bernilai 100 \% karena semua obat yang diresepkan pada pasien pneumonia di RS. Provinsi Sulawesi Tengah periode 2017 sesuai dengan keadaan patologi dan fisiologi pasien serta tidak menimbulkan kontraindikasi pada pasien. Ketepatan pasien ialah ketepatan pemilihan obat yang mempertimbangkan keadaan pasien sehingga tidak menimbulkan kontraindikasi kepada pasien secara individu. Evaluasi ketepatan pasien pada penggunaan antibiotik dilakukan dengan membandingkan kontraindikasi obat yang diberikan dengan kondisi pada data rekam medik.

\section{c) Tepat Dosis}

Tepat dosis adalah ketepatan jumlah obat yang diberikan pada pasien, dimana dosis berada dalam range dosis terapi yang direkomendasikan serta disesuaikan dengan usia dan kondisi pasien. Misalnya pasien anak $>60 \mathrm{~kg}$ biasanya disarankan menggunakan dosis dewasa. Usia Lanjut atau pasien dengan 
kerusakan ginjal dan hati biasanya memerlukan penyesuaian dosis.

Pada data ketepatan dosis, penggunaan antibiotik untuk tepat dosis semuanya sudah sesuai dengan standar yang dianjurkandan tidak menemukan kesalahan pemberian dosis. Hal ini dapat di lihat pada pada tabel 4 yang menunjukkan bahwa tidak terdapat satupun kesalahan pemberian dosis, sehingga untuk evaluasi ketepatan dosis antibiotik di Rumah Sakit Provinsi Sulawesi Tengah mencapai 100\%.

\section{d) Waspada Efek Samping}

Masalah efek samping tidak bisa dikesampingkan karena dapat menimbulkan berbagai dampak dalam penggunaan obat baik dari sisi ekonomi, psikologi dan keberhasilan terapi. Evalusi efek samping obat yang diberikan pada pasien anak penderita penyakit bronkopneumonia di Rumah Sakit Provinsi Sulawesi Tengah periode Januari - Juli 2017 dapat dilihat dari efek samping yang ditimbulkan oleh obat yang digunakan. Persentase pengunaan obat berdasarkan waspada efek samping diperoleh nilai 100\% sudah sesuai (tidak menimbulkan efek samping). Dimana penggunaan antibiotik pada pasien anak penderita penyakit Bronkopneumonia di Rumah Sakit Provinsi Sulawesi Tengah periode Januari - Juni 2017 tidak menimbulkan efek samping.

Pemberian obat potensial menimbulkan efek samping yaitu semua efek yang tidak diinginkan yang timbul dan dapat membahayakan atau merugikan pasien (adverse reactions) akibat penggunaan obat dengan dosis terapi tertentu (Swestika, 2013).

\section{KESIMPULAN}

Berdasarkan hasil penelitian tentang evaluasi penggunaan antibiotik pada pasien penderita penyakit broncopneumonia di Rumah Sakit Provinsi Sulawesi Tengah periode Januari - juni 2017 dapat disimpulkan bahwa dari 42 pasien terdapat 42 pasien $(100 \%)$ tepat indikasi, 42 pasien (100\%) tepat obat, 42 pasien $(100 \%)$ tepat pasien dan tepat dosis sebanyak 42 pasien (100\%). Sehingga didapatkan pemberian antibiotik yang rasional sebanyak $100 \%$ dari total 42 pasien anak Broncopneumonia usia 0-11 tahun di Rumah Sakit Provinsi Sulawesi Tengah periode Januari - juni 2017.

\section{TERIMA KASIH}

Terimakasih sy ucapkan kepada keluarga, sahabat yang telah membantu selama proses penelitian. 


\section{DAFTAR PUSTAKA}

Ramadheni, P. 2018. Analisis Penggunaan Antibiotika Parenteral Pada Pasien Bronkopneumonia Di Ruang Rawat Inap Penyakit Dalam Rsup Dr. M. Djamil Padang. Social Clinical Pharmacy Indonesia Journal, 3(2), 1-8.

Depkes, 2005. Pharmaceutical Care Untuk Infeksi Saluran Pernapasan, Hal 2734. Departemen Kesehatan Republik Indonesia, Jakarta

Sawitri, G. A. 2013. Bronkopneumonia. Jurnal Medula, 1(02), 63-71.

Alaydrus, S. (2017). Profil Penggunaan Obat pada pasien Hipertensi di Puskesmas Marawola Periode Januari-Maret 2017. Jurnal Mandala Pharmacon Indonesia, 3(02), 110-118.

Fadhila, A. (2013). Penegakan diagnosis dan penatalaksanaan bronkopneumonia pada pasien bayi laki-laki berusia 6 bulan. Jurnal Medula, 1(02), 1-10.

Ginting, M. H., Rosidi, A., \& SU, Y. N. (2015). Perbedaan Tingkat Kecukupan Karbohidrat dan Status Gizi (BB/TB) dengan Kejadian Bronkopneumonia Pada Balita Usia 1-5 Tahun di Puskesmas Purwoyoso Semarang. Jurnal Gizi, $4(2)$.

Variandini, Rise, Hariyanto 2017. Evaluasi Kesesuaian Dosis Pada Pasien Pediatri Bronkhitis akut dirumah sakit tentara kartika husada kubu raya. Pharm Sci Res ISSN 2407-2354. Vol.4 No.2 2017

Baharirama, Artini. Pola Pemberian Antibiotika untuk pasien community Acquired Pnemonia anak di instalasi rawat inap RSUD Buleleng Tahun 2013. E-jurnal Medika, Vo.6 N0 3, Maret 2017.

Efni, Machmud, Pertiwi. Faktor resiko yang berhubungan dengan kejadian Pnemonia pada balita di Kelurahan Air tawar barat padang.
Artikel Penelitian.

Kesehatan Andalas. 2016

Purnawan ON. Pumiti s, Bagus SI. Faktorfaktor yang berhubungan dengan pneumonia pada anak usia 2 bulan - 5 tahun. Jurnal ilmu kesehatan anak. RSUP Sanglah Universitas Udayana. 2012 